() Turova L., Kurchenko A., 2020

doi:10.37321/immunology.2020.3-4-09

УДК 612.6.052-63

\title{
IMMUNOGENETIC PREDICTORS OF RISK OF MISCARRIAGE
}

\author{
TUROVA L., KURCHENKO A.
}

Department of Clinical Immunology, Allergology with Section of Medical Genetics

\author{
National Medical University named after O. Bohomolets
}

The problem of miscarriage in the field of perinatology and obstetrics is one of the most important. Despite the large number of scientific studies, the level of preterm birth tends to increase in the vast majority of countries [1-4].

In Ukraine the frequency of miscarriage reaches $15-27 \%$ of all diagnosed pregnancies $[3,5]$.

Miscarriage can be considered as a multifactorial pathology that is a universal integrated response of the female body to any health problems of the pregnant woman, fetus and the environment, the result of functionally impaired variants (alleles) of many genes against adverse external and internal factors.

In the modern world, medicine based on the principles of $4 p$ has the greatest prospects: predic- tive; precaution; participatory - the patient is a participant in the treatment process; personificationindividual. And it is molecular diagnostics based on the individual structure of the human genome and the peculiarities of the metabolic processes of his body can give the right information about the possible development of certain mulfactorial diseases and miscarriage as well. Different genes have different degrees of involvement in the development of the disease, and by combining their roles, it is possible to predict the possible development of a particular condition.

Among the causes of miscarriage are (Fig.1):

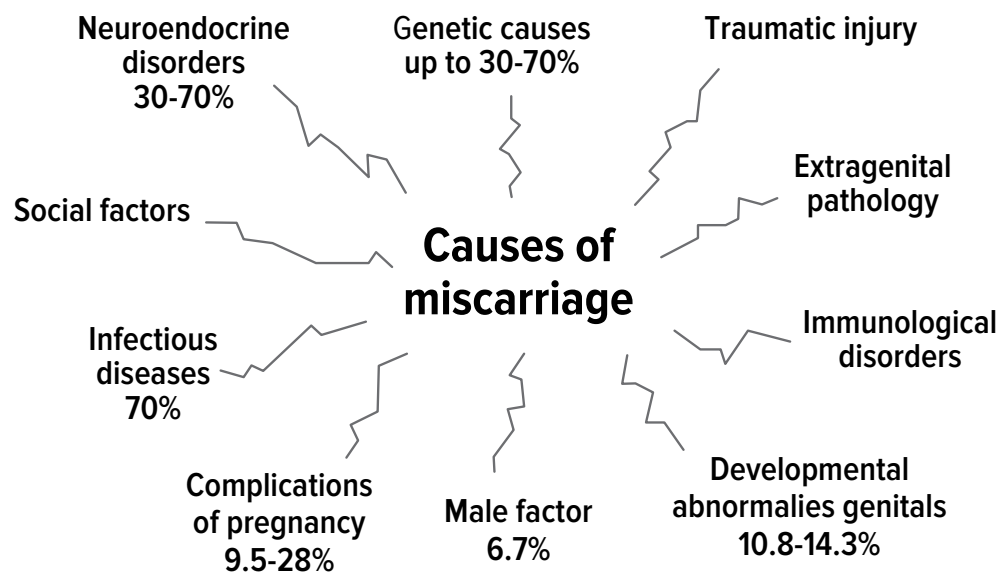

Fig.1. Causes of miscarriage

A special place in the structure of miscarriage is occupied by a genetic factor. Among the genetic causes of miscarriage are chromosomal abnormalities, gene mutations and hereditary predisposition Most chromosomal abnormalities are not inherited and occur de novo in the gametes of the parents or in the early stages of zygote division. Up to $95 \%$ of chromosomal and genomic mutations lead to early termination of pregnancy $[3,6,7]$.

Chromosomal aberrations in the embryo can occur under the influence of chemical, physical (radiation, temperature shock) and biological (gamete suspicion, viral infections) factors. The damaging factor can be exogenous (most mutagens of any etiology) or endogenous in origin, mainly due to dysfunction of genes for inactivation of toxic metabolites or genes for DNA repair, under the influence of stress or disturbance of hormonal homeostasis. Factors of endogenous nature include autoimmune thyroiditis and diabetes, exogenous - smoking (active, passive), drugs

The shorter the gestation period, the higher the frequency of chromosomal abnormalities in the fetus. Chromosomal abnormalities are found in 50\% of abortions in the first trimester of pregnancy. In $49.8 \%$ of early abortions there are complete trisomies of autosomes, in $23.7 \%$ - X- monosomy and in $17.4 \%$ - polyploidy, mainly triploidy $[3,6]$. 


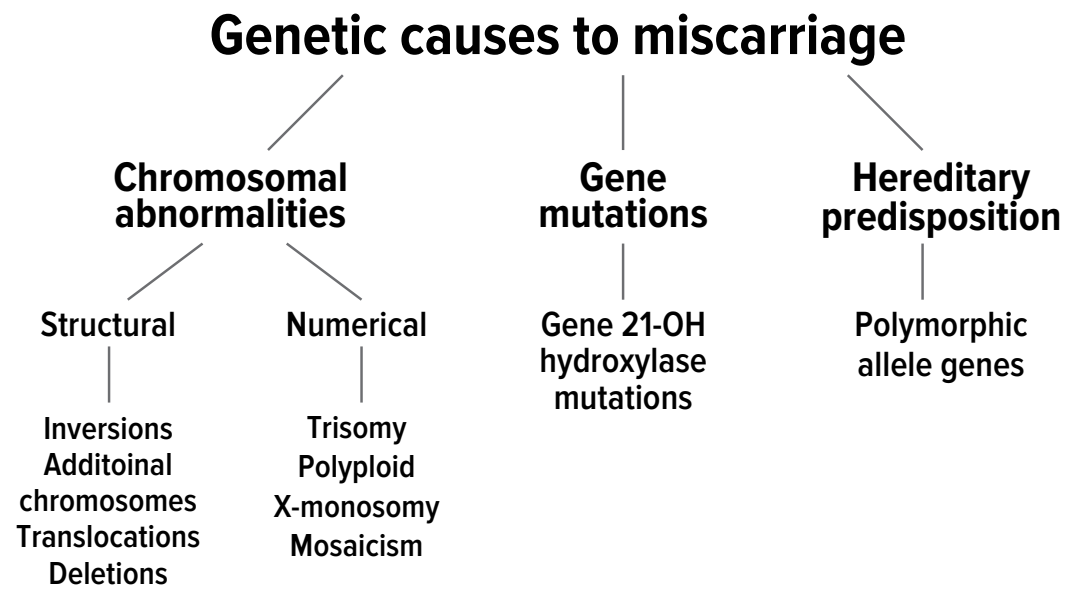

Fig.2.Genetic causes of miscarriage

Most chromosomal abnormalities are not inherited and occur de novo in the gametes of the parents or in the early stages of zygote division. Up to $95 \%$ of chromosomal and genomic mutations lead to abortion at different times.

Chromosomal aberrations in human embryos can occur under the influence of a variety of chemical (mutagens), physical (radiation, temperature shock) and biological (gamete maturation, viral infections) factors. Harmful factors can be exogenous (most mutagens of any etiology) or endogenous in origin, mainly due to metabolic errors, dysfunction of genes for inactivation of toxic metabolites (free radicals, peroxides, etc.) or DNA repair genes, under the influence of stress or disturbances. Among the exogenous factors are smoking (active and passive), various chemicals and drugs. Among the factors of endogenous nature are primarily autoimmune thyroiditis and diabetes mellitus.

Based on large-scale cytogenetic studies of abortion material in the 60s and 80 s of the XX century, it was found that the shorter the gestation period, the higher the frequency of chromosomal abnormalities in the fetus. Chromosomal abnormalities are found in $50 \%$ of abortions in the first trimester of pregnancy, in $25-30 \%$ of fetuses who died before 18 weeks, and in 7\% - after the 20th week. By the time of birth, the total frequency of spontaneous chromosomal abnormalities is in the range of $0.5-0.9 \%$ [8].

Cytogenetic examination of spontaneous abortions reveals various variants of chromosomal abnormalities. Complete trisomies of autosomes occur in $49.8 \%$ of early abortions, X-monosomy in $23.7 \%$, and polyploidy (mostly triploidy) in $17.4 \%$. Almost every 10th miscarriage is triploid [ 8 ].

Numerous studies over the past half century have found that the frequency of chromosomal abnormalities in couples leading to miscarriages ranges from 1.3 to $22.7 \%$. According to foreign and domestic authors, when conducting cytogenetic analysis in married couples with a history of miscarriages, the frequency of chromosomal abnormalities is $3-8 \%$. Carriers of chromosomal rearrangement in $75 \%$ of cases were women. At cytogenetic research of karyotypes of spouses with spontaneous miscarriages of early terms in the anamnesis reveal translocations, inversions, additional chromosomes, mosaicism and others.

The risk of miscarriage in families with balanced chromosomal adjustments is much higher than the risk of giving birth to a child with malformations and, depending on the nature of the adjustment, is in the range of $13-40 \%$. Family chromosomal rearrangements are the cause of karyotype abnormalities in $8.7 \%$ of fetuses. Among married couples with repeated miscarriages, carriers of chromosomes with polymorphism of heterochromatin regions are significantly more common $[8,9,10]$.

Miscarriage can be considered as a multifactorial disease - the result of the action of functionally weakened variants (alleles) of many genes against the background of adverse external and internal factors. The relative role of each genetic and environmental factor is different in each case. These are usually variants of normal genes (alleles) that can contribute to the development of the disease under adverse environmental conditions. These are the so-called "predisposition" genes $[2,3,7,11]$.

It should be noted that hereditary predisposition to any obstetric pathology (miscarriage, preeclampsia, placental insufficiency) does not imply the transmission to the offspring of this pathology as such, but involves the transfer of the corresponding alleles of predisposition genes that determine the high probability of developing this disease.

The relationship between genetic variants and body functions attracts the attention of many researchers, as it allows to more accurately determine the clinical significance of each specific polymorphism. 
Studies in recent years have shown that the body's susceptibility to the harmful effects of the environment depends on the activity of enzymes in the detoxification system of xenobiotics. In the presence of weakened variants of such genes, the risk of some diseases of the reproductive system (endometriosis, miscarriage, preeclampsia, placental insufficiency, etc.) increases $[7,11]$.

\section{Hereditary predisposition \\ Polymorphic alleles of predisposition genes}

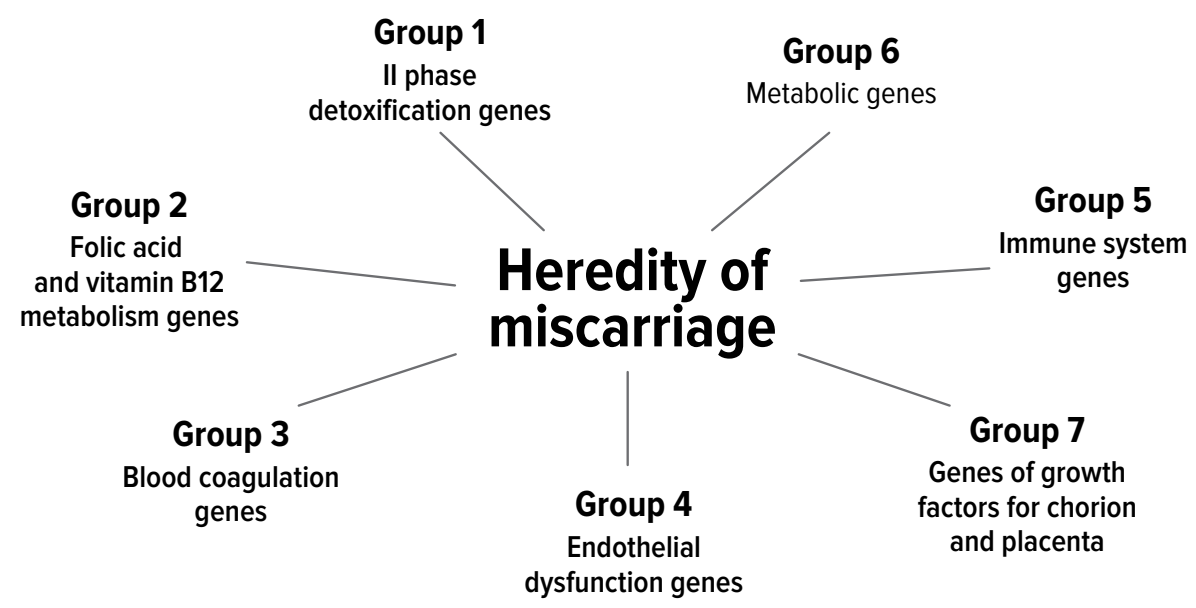

Fig.3. Hereditary predisposition. Polymorphic alleles of predisposition genes

The group of detoxification phase II genes is represented by the glutathione transferase (GST) superfamily. Glutathione-mediated detoxification plays a key role in the neutralization of lipid peroxidation (LPO) products and DNA peroxides, in the reduction of organic hydroperoxides to alcohols, and in the isomerization of certain steroids and prostaglandins. It is known that the intensification of LPS associated with the polymorphism of the detoxification system has a toxic effect on cell biomembranes. It is also shown that the imbalance in the system POL - antioxidant system (AOC) may be due to a decrease in the concentration of steroid hormones in the blood, which is also significant in the pathogenesis of miscarriage.

It is known that GST, characteristic of phase II detoxification enzymes, is present in a variety of tissues and begins to be expressed in the embryonic period of development. Polymorphism of genes controlling their synthesis can lead to an increase or decrease in the activity of the corresponding enzymes and, thus, cause an imbalance between enzymes of phases I and II. The consequence of such an imbalance may be the accumulation in the mother, father and fetus of various toxins. to the threat of abortion in the early stages.

Testing of phase II detoxification genes allows to identify individuals with "fast" and "slow" types of xenobiotic metabolism and to determine the tactics of these patients, as well as to organize the rational prevention of miscarriage.

Over the last decade, the group of genes involved in the metabolism of folic acid and vitamin
B12 has been well studied. High concentrations of the active form of folic acid are necessary for the conversion of excess homocysteine into methionine. Cofactors of methionine metabolic pathways are vitamins, the most important of which are folic acid, pyridoxine (vitamin B6), cyanocobalamin (vitamin B12) and riboflavin (vitamin Bj). The folate cycle is a complex cascading process involving many different enzymes. The main 4 enzymes that ensure the conversion of folic acid at different stages of the cycle are MTHFR, MTRR, MTR and TC. It is known that decreased activity of these enzymes is one of the important reasons for the accumulation of homocysteine in the body.

Summarizing the literature, we can identify several possible causes of elevated levels of homocysteine in women and fetuses:

- Damaging effects of homocysteine on vascular endothelium and stimulation of thrombosis lead to the development of a number of pregnancy complications, including placental abruption and fetoplacental circulatory disorders, which can result in infertility and miscarriage.

- Elevated homocysteine levels in later pregnancies may cause placental insufficiency and, as a result, intrauterine growth retardation and chronic fetal hypoxia.

- There is a positive correlation between the level of homocysteine in the blood in pregnant women and the severity of preeclampsia [12]. 
One of the important factors contributing to the increase in homocysteine levels in the blood may be hereditary predisposition. On to date, the polymorphism of the MTHFR, MTRR, and MTR genes has been studied. The products of these genes enzymes - are involved in one stage of metabolism. A number of researchers have noted a significant increase in the risk of obstetric pathology associated with elevated levels of homocysteine in the blood, in the presence of some polymorphic alleles in several folate cycle genes. For polymorphism of MTHFR, MTRR, MTR, TC genes, a number of authors have also shown a significant association with reproductive pathology and, in particular, with miscarriage [13].

The polymorphism of the MTHFR C / T gene is the most studied. The C677T allele is the result of a point mutation that replaces alanine with valine. In this case, the normal allele is the $C$ allele, the mutant allele is $\mathrm{T}$. The thermolabile variant $677 \mathrm{~T}$ is associated with a violation of folate metabolism, resulting in increased levels of homocysteine and thrombophilia. Carriers of the $T$ allele have a folic acid deficiency during pregnancy.

Despite the large number of studies examining the S / T polymorphism of the MTHFR gene in patients with a history of miscarriage, there is still no consensus on the existence of such an association.

Thus, the work of scientists from different countries in Europe, Asia and America confirmed that the presence of the T allele of the MTHFR gene increases the risk of habitual fetal loss by $4-10$ times. Moreover, one recent study demonstrated the association of $\mathrm{C} / \mathrm{T}$ polymorphism of the MTHFR gene even with a single history of spontaneous miscarriage.

According to some data, not only the maternal genotype but also the fetal genotype is of great importance in miscarriage. Thus, the study of abortive material showed a significant increase in the risk of miscarriage (14 times) in the presence of the embryo alleles of the gene MTHFR 677T and / or $1298 \mathrm{C}$ in a homo- or heterozygous state. Given the important role of folic acid in the metabolism of nucleic acids, and hence in the processes of proliferation and differentiation, disruption of the folate cycle is extremely dangerous for rapidly dividing embryonic cells $[13,14]$

Elevated homocysteine levels may be accompanied by the development of secondary autoimmune reactions and are currently considered as one of the possible causes of antiphospholipid syndrome. Thus, in a study by Brazilian scientists, in women with a history of miscarriage and the presence of antiphospholipid syndrome, the frequency of the 677 T allele $(40.3 \%)$ was significantly higher than in the control. In PNB, this allele is considered as a predisposing factor to thrombosis.
Another fairly commonly studied polymorphism is MTHFR A1298C. The association of this allelic variant with miscarriage is shown. An increased incidence of A / C and C / C genotypes of the MTHFR gene has been reported in women with a history of early miscarriage. It is noteworthy that in the studied groups in no case were found two polymorphic variants of the MTHFR gene on one chromosome. This indicates the independent occurrence of C677T and $\mathrm{A} 1298 \mathrm{C}$ polymorphisms. It is possible that the presence of two substitutions in the MTHFR gene on one chromosome is lethal [14].

The polymorphism of the MTHFR C677T and MTRR A66G genes has been studied most fully. A pronounced association of these polymorphisms with miscarriage, as well as with Down syndrome and spina bifida has been shown [15].

The association of polymorphism of two genes MTRR A66G and MTR A2756G with the development of miscarriage was also found [16].

It is known that in the uncomplicated course of pregnancy develops physiological adaptation in the hemostasis system, characterized by a gradual increase in blood coagulation potential by increasing the activity and quantitative content of most coagulation factors by 1.5-2.5 times and reducing anticoagulant potential. Occurrence of microthrombosis during pregnancy is a frequent cause of various obstetric pathology (gestosis, placental insufficiency, premature detachment of the normally located placenta, habitual fetal loss, etc.) [17-19].

It is known that the presence of antiphospholipid antibodies in the blood of women increases the risk of venous, arterial and placental thrombosis during pregnancy, which may result in habitual fetal loss. In one study, however, no significant association was found between miscarriage in women with antiphospholipid syndrome and mutations in the FV and RTM genes [18].

Significant differences in the frequency of G1691A mutations in the FV gene and G20210A mutations in the RTM gene between patients with habitual fetal loss and healthy women were identified by Greek authors. The association of heterozygous G / A genotypes of the FV gene $(p<0.003)$ and $G / A$ of the RTM gene $(p<0.038)$ with the development of miscarriage was shown. In addition, the frequency of the G / A genotype of the FV gene was significantly different in the group of women with 2 miscarriages (8.5\%), compared with patients with a history of 3 miscarriages $(26.6 \%$; $p$ $<0.04)$. The association of these genotypes with the risk of recurrent miscarriages in both the first and second trimesters has been established. In patients with habitual fetal loss in the second trimester, the frequency of mutations in both genes is higher than with miscarriages in the first trimester of pregnancy[19]. 
Thrombophilic complications may also be due to the presence of the G455A mutation in coagulation factor I (the fibrinogen gene). This mutation can lead to elevated levels of fibrinogen in the blood and / or changes in the structure of fibrinogen. According to the literature, $20 \%$ of dysfibrinogenemia manifests itself as thrombosis, which may result in miscarriage $[1,3,20]$.

It is known that the main link in the pathogenesis of many diseases, including obstetric pathology: preeclampsia, placental insufficiency, miscarriage, is endothelial dysfunction. The endothelium synthesizes substances involved in blood coagulation and fibrinolysis, regulation of vascular tone and permeability, angiogenesis, etc. When damaged, endothelial cells begin to produce procoagulants, vasoconstrictors and growth factors [21, 22].

Studies in recent years have shown that among the etiopathogenetic risk factors for miscarriage, the leading place belongs to endothelial dysfunction both in the maternal body and in the fetoplacental complex and in the arteries of the umbilical cord. It is known that angiotensin-converting enzyme (ACE) (a key enzyme of the renin-angiotensin system) is one of the important links in maintaining the balance between the factors of vasoconstriction and vasodilation, and therefore the regulation of vascular tone. This enzyme controls the conversion of angiotensin I to angiotensin II, which in turn is one of the vasoconstrictors. Changes in the level of vascular metabolites play an important role in the functioning of the fetoplacental complex and can lead to impaired regulation of blood circulation in the placenta[22].

Insertion / deletion (I / D) of the Alu repeat 287 bp plays a major role in the regulation of vascular tone. in the 15th intron of the ACE gene. According to some researchers, I / D polymorphism is associated with changes in the level of ACE gene expression. The presence of the $D$ allele correlates with a significant increase in the amount of ACE in blood plasma. The ACE I allele is functionally less active than the $D$ allele. The association of the D-allele of the ACE gene with cardiovascular diseases, in particular, with hypertension and with some forms of preeclampsia has been proven. Significant differences in the frequency of the ACE D / D genotype and the 4G / 4G genotype of the PAl-1 gene were found between patients with PNB and control $[23,24]$.

A type I tissue plasminogen activator inhibitor (PA1-1) is a central component of the fibrinolytic system. It inhibits uro-kinase, protein $\mathrm{C}$ and tissue plasmin gene activator. The 4G / 5G polymorphism of the PA1-1 gene is associated with PA1-1 activity in the blood, while the $4 \mathrm{G}$ allele is associated with a higher level of PA1-1. This polymorphism is a risk factor for the development of thrombosis, myocardial infarction, gestosis, fetal malnutrition, stillbirth, etc. [24].
The formation of vasoactive substances plays an important role in the development of these processes. Among them, a special place belongs to nitric oxide (NO), which has pronounced vasodilatory properties. According to modern concepts, nitric oxide plays the role of a universal regulator of many physiological processes, including the maintenance of cardiovascular homeostasis, immune status, cytotoxic activity of macrophages, etc. N0 can be synthesized by many cells in the body, including vascular endothelial cells, some neurons, platelets, adrenal medulla cells, macrophages, etc. According to the latest data, NO is synthesized in the trophoblast, placenta, and myometrium of pregnant women $[25,26]$.

In the gene of endothelial nitroxide synthetase (eNOS), 4 polymorphic variants are described: A27C in intron 18; G10T in intron 23; 4a / 4b polymorphism in intron 4 and structural polymorphism Glu298Asp in exon 7. Polymorphism in intron 4 is represented by 2 alleles: $4 \mathrm{~b}$ allele, in which there are 5 repeated fragments of $27 \mathrm{bp}$ in length, and a $4 a$ allele, in which there are 4 such repeats. In homozygotes for allele $4 a$, the level of nitrates and nitrites in the blood, which is directly related to the rate of NO production by the vascular endothelium, is significantly lower than in individuals with genotype $4 \mathrm{~b} / 4 \mathrm{~b}$. This indicates the influence of this polymorphism on the level of gene expression.

An association of the $4 \mathrm{a} / 4 \mathrm{~b}$ polymorphism of the eNOS gene with miscarriage and intrauterine growth retardation was revealed The frequency of allele $4 a$ was significantly higher $(p<0.05)$ with habitual fetal loss $(20 \%)$ than in the control $(11 \%)[25,26]$.

In recent years, the role of genes of the main human histocompatibility complex (Human Leukocyte Antigen - HLA) in the genesis of habitual fetal loss has been widely studied. The HLA system controls the interaction of all immunocompetent cells of the body, recognizes its own and foreign (including changed own) cells, triggers and implements the immune response and, in general, ensures the survival of a person as a species under conditions of exogenous and endogenous aggression.

The problem of spousal compatibility under the HLA system and its importance in reproduction remains unresolved at the moment. Deciphering the human genome, perhaps, will make it possible to more closely relate the features of the HLA system of the mother, father and fetus with obstetric pathology.

The incompatibility of the spouses in terms of HLA antigens, as well as the incompatibility of the embryo and the maternal organism in this system, is an important point necessary for maintaining and carrying a pregnancy. According to some data, the compatibility of spouses for 2 or more antigens of the HLA system increases the risk of miscarriage most $100 \%[7,22,27,28]$. 
We consider it appropriate to examine the spouses both after 2 spontaneous miscarriages and after one history of miscarriage. When matching spouses at 2 or more loci system, as well as in the presence of certain genotypes predisposing to miscarriage propriate treatment is necessary. One of the methods is the immunization of such women with marital T- and B-lymphocytes, since the appearance of antibodies to the husband's HLA antigens increases the chance of a favorable outcome of each subsequent pregnancy and the birth of term babies.

It is known that with insufficient ovarian function, pregnancy is usually terminated in the first trimester. The progesterone receptor mediates the physiological effects of the hormone. It exists in two isoforms - PR-A and PR-B. PR-A inhibits estrogen- or progesterone-induced cell proliferation, while PR-B potentiates it. Several major mutations in the progesterone receptor gene located on the long arm of chromosome 11 are known: polymorphism 331G / A in the promoter part of the gene and polymorphism 1031G / C in exon 1, $1978 \mathrm{G} / \mathrm{T}$ in exon 3, $2310 \mathrm{C} / \mathrm{T}$ - in the 5th exon, an insertion in the $\mathrm{G}$ intron called PROGINS, etc.

It is known that the $331 \mathrm{G} / \mathrm{A}$ polymorphism of the PGR gene increases the expression of the PR-B isoform and is associated with endometrial and breast cancer. Recent studies have demonstrated the association of $331 \mathrm{G} / \mathrm{A}$ polymorphism with the level of prolactin in the blood [ 27,29$]$.

One study found an increase in the frequency of the $T$ allele and the $C$ / T genotype and $T$ / T polymorphism IVS1-401C / T of the estrogen receptor gene in women with a single history of late miscarriage [29].

The symptomatics of the threatened miscarriage in the first trimester may develop due to conversion of initial inflammatory reaction that disturbs the intersystemic and local interactions in the endometrium, followed by placental insufficiency, intrauterine fetal affection and spontaneous abortion. The aim of our work was to study the association between single nucleotide polymorphisms (SNPs) of some cytokine genes, e.g., IL$1 \beta$ (C511T, rs16944), IL-17A (G197A, rs2275913), IL-12B (A1188C, rs3212227), TNF $\alpha$ (G308A, rs1800629), and IL-4 (C589T, rs2243250) and the risk of early reproductive losses among residents of Adyghe Republic (RA). The work was carried out at the Immunogenetic Laboratory of our Research Institute of Complex Problems. The allelic variants of cytokine genes were detected by SNP-method in 106 samples of genomic DNA in women with the threatened abortion in 1st trimester $(n=58)$ and the uncomplicated gestation $(n=48)$. SNP-typing of polymorphic variants of cytokine genes IL-1 $\beta$, IL17A, IL-12B, TNF $\alpha$ and IL-4 was carried out by PCR (polymerase chain reaction) with allele-specific primers and electrophoretic detection of results on test systems of (Litech, Moscow). Statistical analysis of experimental data was carried out by SPSS Statistical program 17.0. The correspondence of SNP distributions to expected values at HardyWeinberg equilibrium and comparison of allelic variants/ genotypes frequencies were performed using the $\chi 2$ criterion (Chi-square with Yates correction), odd ratios (OR) detected at significance level $p<0.05$ and $95 \%$ confidence interval $(95 \%$ $\mathrm{Cl})$. Reliability of the differences for the SNP frequencies for small samples was evaluated using the Fisher's exact criterion. Heterozygous variant (C511T; OR $=3.46 ; 95 \% \mathrm{Cl}: 1.04-11.54)$ and homozygous "mutant" genotypes (T511T; OR $=5.71$; $95 \% \mathrm{Cl}: 1.12-29.09)$ of the main proinflammatory IL- $1 \beta$ was significantly associated $(p<0.05)$ with the risk of developing threatening miscarriage in the Adygea residents. The $-511 \mathrm{~T}$ allele of IL- $1 \beta$ gene, and $-1188 \mathrm{C}$ variant of IL-12B gene increase the risk of the early termination of pregnancy, respectively, 5.8-fold (95\% Cl: 2.4213.92; $p=0.00004$ ), and 2.97 -fold (95\% Cl: $1.23-7.19 ; p=0.01)$. The "mutant" $-511 \mathrm{~T}$ allelic variant of the IL-1 p gene is associated with the risk of developing a symptome complex of threatening miscarriage in Russian ethnic group $(p=0.0001 ; O R=14.09)$, and in Adygea ethnic group $(p=0.02$; OR $=8.17)$, which is almost undetectable in women with normal pregnancy in the first trimester. Thus, only C511T (rs16944) in IL$1 \beta$ gene and $A 1188 C$ (rs3212227) in IL-12B gene of the five typed cytokine genes may be used as marker polymorphisms of gestational distress for the women in Adygea [30].

The study was conducted in 133 pairs of newborns born at 28-36 weeks of gestation.

Division into groups depending on gestational age, type of pathology and degree of morphofunctional maturity: I group - 32 children with SMI CNS according to their gestational age, II group 38 newborns with SMI CNS and ZVUR, III group - 30 examined with VUI, IV group - 33 patients with RDS.

The comparison group consisted of 30 women with physiological pregnancies and relatively healthy preterm infants with a relatively successful neonatal period who were with their mothers and received on-demand breastfeeding.

The subject of research is allelic polymorphism of GSTT1, GSTM1, GSTP1 and MTHFR, MTR, MTRR, IL-6, IL-8, IL-10, eNOS, CYP1A1 genes in mother-newborn pairs.

\section{Genetic portraits of the subjects:}

1. The most common gene interactions in women with miscarriage are the following combinations:

2. Heterozygote of polymorphic variant - $1082 \mathrm{G}$ / A of gene IL10, + IL6, polymorphic variant 
CYP1A1 + homozygote of gene (variant A313G of GSTP1 gene and homozygote of polymorphic variant C677T of gene MTHFR = prematurity and perinatal pathology

3. Heterozygote of polymorphic variant $4 \mathrm{a} / 4 \mathrm{~b}$ of eNOS gene + polymorphic variant C781T of IL8 gene, polymorphic variant $(592 \mathrm{C} / \mathrm{A})$ of IL10 gene + polymorphic variant $1082 \mathrm{G} / \mathrm{A}$ of IL10 gene + polymorphic variant $(174 \mathrm{G} / \mathrm{C})$ of IL6 gene.

\section{Conclusion:}

Changes at the gene level (polymorphisms) only create the necessary prerequisites for the development of multifactorial pathology. The human body has a complex hemostasis system with adaptive properties. With a combination of defective functionally weakened alleles against the background of the action of adverse (provoking) environmental factors, such polymorphisms can play an important role in the pathology of pregnancy and impaired embryonic development.

Early molecular DNA diagnosis will help doctors predict the course of $\mathrm{HB}$ and rule out the possibility of late manifestation of any other symptoms in the newborn.

Examination of a married couple who already has a sick child for the presence of mutations characteristic of the disease makes it possible to assess the sporadic or familial nature of the disease. Plan and implement a healthy pregnancy.

Opens the possibility of diagnostic search "without a hypothesis", to identify molecular mechanisms, informing which genes, signaling cascades or metabolic pathways are damaged in the patient's body.

\section{СПИСОК ЛИТЕРАТУРЫ}

1. Соловей В.М. Сучасні погляди на предиктори невиношування вагітності (огляд літератури). Буковинський медичний вісник. Т.24, № 1 (93). С. 250-256.

2. Живецкая-Денисова А.А, Воробьева И.И, Ткаченко В.Б, Рудакова Н.В. Невынашивание беременности: современные подходы к диагностике, профилактике и лечению. Перинатология и педиатрия. 2017; 2(70):91-98.

3. Воробйова І.І., Живецька-Денисова А.А., Ткаченко В.Б., Рудакова Н.В., Толкач С.М. Невиношування вагітності: сучасні погляди на проблему (Огляд літератури). Здоров'я жінки. 2017;3(119):113-16.

4. Жук С.І. Проблема невиношування вагітності в сучасному акушерстві. [Електронний ресурс] Доступно: http://ag1.bsmu.edu. ua/novini/ untitledpost/naukovij-simpoziumzmiznarodnou-ucastu-reproduktivne-zdorov- a-molodi/s-i-zukproblema-nevinosuvannavagitnosti-v-sucasnomu-akuserstvi.

5. Давиденко К. Пленум Асоціації акушерівгінекологів України: актуальні та дискусійні питання [Електронний ресурс]. Доступно: https://www.umj.com.ua/article/163339/ plenumasotsiatsiyi-akusheriv-ginekologivukrayini-aktualni-ta-diskusijnipitannya.

6. Машкина Е.В. Молекулярно - генетические предикторы репродуктивных потерь. Белгород; 2015. 205 с.

7. Воробйова І.І., Скрипченком Н.Я. Імуногенетичні підходи до діагностики невиношування вагітності як мультифакторіального захворювання. Методичні рекомендації. Київ; 2016. - 30 с.

8. Stephenson MD. Cytogenetic analysis of miscarriages from couples with recurrent miscarriage: a case-control study / Stephenson M. D., Awartani K. A., Robinson W. P. // Hum. Reprod. - 2002. - Vol. 17. P. 446-451.

9. Баранов В.С. Геном человека и гены «предрасположенности». Введение в предиктивную медицину / Баранов В.С., Баранова Е.В., Иващенко Т.Э., Асеев М.В. - СПб.: Интермедика, 2000. - 271 с.

10. ВовкІ.Б., ВдовиченкоЮ.П., ТрохимовичО.В., Задорожна Т.Д., Горовенко Н.Г. Ранні репродуктивні втрати. Київ: 2016. 253 с.

11. Каліновська І.В. Генетичні аспекти невиношування вагітності Буковинський медичний вісник Том 20, № 2 (78), 2016

12. Metabolic gene polymorphism frequencies in control populations / Garte S., Gaspari L., Alexandrie A. [et al.] //Cancer Epidemiology Biomarkers Prevention. - 2001. - Vol. 10. P. $1239-1248$

13. Genetic factors in fetal growth restriction and miscarriage /amada H., Sata F., Saijo Y. [et al.] // Semin. Thromb. Hemost. - 2005. Vol. 31, N 3. - P. 334-345

14. Zetterberg $H$. Methylenetetrahydrofolate reductase and transcobalamin genetic polymorphisms in human spontaneous abortion: biological and clinical implications / Zetterberg H. // Reprod. Biol. and Endocr. 2004. - Vol. 2. - P. 7.

15. Methionine synthase (MTR) 2756 $(A \rightarrow G)$ polymorphism, double heterozygosity methinine synthase 2756 AG/ methionine synthase reductase (MTRR) $66 \mathrm{AG}$, and elevated homocysteinemia are three factors for having a child with Down syndrome / Bosco P., Gueant-Rodriguez R. M., Anello G. [et al.] // Am. J. Med. Genet. A. - 2003. - Vol. 121, N 3. -P. 219-224. 
16. MTHFR C677T Polymorphism and factor $\mathrm{V}$ Leiden mutation are not associated with recurrent spontaneous abortion of unexplained etiology in Japanese women / Kohashi G., Kato E.H., Morikawa M. [et al.] // Semin. Thromb. Hemost. - 2005. - Vol. 31, N 3. P. 266-271.

17. Analyzes of three common thrombophilic gene mutations in German women with recurrent abortions / Pauer H. U., Voigt Tschirschwitz T., Hinney B. [et al.] // Acta Obstet. Gynecol. Scand. - 2003. - Vol. 82, N 10. - P. 942-947

18. Evaluation of the association between hereditary thrombophilias and recurrent pregnancy loss: a meta-analysis /Kovalevsky G., Gracia R., Berlin J. [et al.] // Arch. Intern. Med. -2004. - Vol. 164, N 5. - P. 558-563.

19. Santoro $R$. Prothrombotic gene mutations in women with recurrent abortions and intrauterine fetal death / Santoro R., lannaccaro P., Sottilotta G. // Minerva Ginecol. - 2005. Vol. 57, N 4. - P. 447-450.

20. Thrombophilic gene mutations and recurrent spontaneous abortion: prothrombin mutation increases the risk in the first trimester / Pihusch R., Buchholz T., Lohse P. [et al.] // Am. J.Reprod. Immunol. - 2001. - Vol. 46, N 2. - P. 124-131.

21. Дисфункция эндотелия. Причины, механизмы, фармакологическая коррекция / Под ред. Н. Н. Петрищева. - СПб.: Изд-во СПбГМУ, 2003. - 184 с.

22. Воробйова, І.І. Визначення ролі поліморфізму генів кандидатів у передчасному перериванні вагітності різних термінів. Воробйова І.І., Скрипченко Н.Я., Ткаченко В.Б, Рудакова Н.В, Толкач С.М. ЖивецькаДенісова А.А. Перинатология и педиатрия 3(67)/2016: 61-65

23. Polymorphisms in the ACE and PAI1 genes are associated with recurrent spontaneous miscarriages / Buchholz T., Lohse P., Rogenhofer N. [et al.] // Human Reproduction. - 2003. - Vol. 18, N 11. P. 2473-2477

24. Genetic variation at the human tissue-type plasminogen activator (tPA) locus: haplotypes and analysis of association to plasma levels of tPA / Ladenvall P., Nilsson S., Jood K. [et al.] // European Journal of Human Genetics. - 2003. - Vol. 11. - P. 603-610.

25. Беспалова О.Н. Анализ полиморфизма генов нейрональной (nNOS) и эндотелиальной (eNOS) NO-синтаз при плацентарной недостаточности $(П \mathrm{H})$ и задержке внутриутробного развития пло- да / Беспалова О.Н., Тарасенко О. А., Иващенко Т.Э., Баранов В.С. // Ж. акуш. жен. болезн. -2006. - T. LV, Вып. 1. C. 57-63.

26. Expression of nitric oxide synthase isoforms in human pregnant myometrium at term / Bao S., Rai J., Schreiber J. //J. Soc. Gynecol. Investig. - 2002. - Vol. 9, N 6. P. 351-356.

27. Abbas A. Analysis of human leukocyte antigen (HLA)-G polymorphism in normal women and in women with recurrent spontaneous abortions / Abbas A., Tripathi P., Naik S., Agrawal S. // European Journal of Immunogenetics. 2004. - Vol. 31. - P. 275-278.

28. Булавенко О.В., Мунтян О.А. Прогнозування ризику переривання вагітності у жінок із звичним невиношуванням в анамнезі "BIOMEDICAL AND BIOSOCIAL ANT HROPOLOGY " 2017, №28:147-149.

29. Hviid T.V. Linkage disequilibrium between human leukocyte antigen (HLA) class II and HLA-G-possible implications for human reproduction and autoimmune disease / Hviid T. V., Christiansen O. B. // Hum. Immunol. 2005. - Vol. 66, N 6. -P. 688-699.

30. Татаркова Е.А. ПОЛИМОРФИЗМЫ ГЕНОВ IL-1 в (C511T), IL-17A (G197A), IL-12B (A1188C), TNFa (G308A) И IL-4 (C589T) ПРИ УГРОЗЕ РАННИХ РЕПРОДУКТИВНЫХ ПОТЕРЬ /Татаркова Е.А., Тугуз А.Р. и др.// Медицинская иммунология - 2019 - Т. 21, № 6. - стр. 1179-1186.

\section{SUMMARY \\ IMMUNOGENETIC PREDICTORS OF RISK OF MISCARRIAGE}

Turova L., Kurchenko A.

Department of Clinical Immunology, Allergology with Section of Medical Genetics

National Medical University named after O. Bohomolets

The study of immunogenetic markers associated with the development of complications of pregnancy and perinatal pathology in newborns is of great practical importance for the development of preventive measures and maintaining the health of the baby in the future. Numerous studies in recent years have shown that the presence of genetic predisposition to certain diseases is associated with an increased risk of pregnancy complications (habitual miscarriage, placental insufficiency, late toxicosis), which leads to the implementation of perinatal pathology in later life.

Key words: miscarriage, genes, immunogenetic. 


\section{PEЗ ЮME \\ ІМУНОГЕНЕТИЧНІ ПРОВІСНИКИ РИЗИКУ викидня}

Турова Л.О., Курченко А.І.

Кафедра клінічної імунології, алергології з відділом медичної генетики

Національний медичний університет імені О. О. Богомольця

Вивчення імугенетичних маркерів, асоційованих з розвитком ускладнень вагітності та перинатальної патології у новонароджених, має велике практичне значення для розробки профілактичних заходів та збереження здоров'я малюка у майбутньому. Численні дослідження останніх років показали, що наявність генетичної схильності до певних захворювань пов'язане з підвищеним ризиком розвитку ускладнень вагітності (звичне невиношування, плацентарна недостатність, пізній токсикоз), що призводить до реалізації перинатальної патології в подальшому житті дитини.

Ключові слова: невиношування вагітності, гени, імуногенетика.
PЕЗЮME

\section{ИММУНОГЕНЕТИЧЕСКИЕ ПРЕДВЕСТНИКИ РИСКА ВЫКИДЫША}

Турова Л.А., Курченко А.И.

Кафедра клинической иммунологии, аллергологии с отделом медицинской генетики Национальный медицинский университет имени А. А. Богомольца

Изучение имугенетичних маркеров, ассоциированных с развитием осложнений беременности и перинатальной патологии у новорожденных, имеет большое практическое значение для разработки профилактических мероприятий и сохранения здоровья малыша в будущем. Многочисленные исследования последних лет показали, что наличие генетической предрасположенности к определенным заболеваниям связано с повышенным риском развития осложнений беременности (привычное невынашивание, плацентарная недостаточность, поздний токсикоз), что приводит к реализации перинатальной патологии в дальнейшей жизни ребенка.

Ключевые слова: невынашивание беременности, гены, иммуногенетика.

\section{АВТОРСЬКА ДОВІДКА:}

\section{- Турова Людмила Олександрівна \\ к.мед.н., PhD,. Кафедра клінічної імунології та алергології з секцією медичної генетики Національного медичного університету імені 0.0. Богомольця. \\ Адреса: Київ- 80 , вул. Турівська, 26 \\ Тел .: 0505906271 \\ E-mail: turova_mila@ukr.net}

\footnotetext{
- Курченко Андрій Ігорович доктор медичних наук, професор, завідувач кафедри клінічної імунології та алергології із секцією медичної генетики Національного медичного університету імені 0.0. Богомольця.

Адреса: Київ- 80 , вул. Турівська, 26

Тел.: 050-581-23-45

E-mail: andriy.kurchenko@gmail.com
}

\author{
- Турова Людмила \\ Александровна \\ к.мед.н., PhD. Кафедра клинической имму- \\ нологии и аллергологии с секцией медицин- \\ ской генетики Национального медицинского \\ университета имени А.А. Богомольца. \\ Адрес: Киев-80, ул. Туровская, 26 \\ Тел.: 0505906271 \\ E-mail: turova mila@ukr.net
}

\footnotetext{
- Курченко Андрей Игоревич доктор медицинских наук, профессор, заведующий кафедрой клинической иммунологии и аллергологии с секцией медицинской генетики Национального медицинского университета имени А.А. Богомольца. Адрес: Киев-80, ул. Туровская, 26 Тел .: 050-581-23-45 E-mail: andriy.kurchenko@gmail.com
}

\section{- Turova Lyudmila}

Candidate of Medical Sciences, PhD. Department of Clinical Immunology and Allergology with the Section of Medical Genetics of the National Medical University named after 0 . Bohomolets.

Address: Kyiv-80, str. Turivska, 26

Tel .: 0505906271

E-mail: turova_mila@ukr.net

\footnotetext{
- Kurchenko Andrii

Doctor of Medical Sciences, Professor, Head of the Department of Clinical Immunology and Allergology with the Section of Medical Genetics of the National Medical University named after 0 . Bohomolets. Address: Kyiv-80, str. Turivska, 26 Tel.: 050-581-23-45 E-mail: andriy.kurchenko@gmail.com
} 